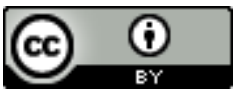

\title{
TINJAUAN HUKUM ADMINISTRASI NEGARA TERHADAP KEPATUHAN WAJIB PAJAK DALAM PROGRAM PENGUNGKAPAN SUKARELA
}

\author{
1)4121210014_asyifa@pknstan.ac.id, Politeknik Keuangan Negara STAN \\ 2)4111210007_camelia@pknstan.ac.id,Politeknik Keuangan Negara STAN \\ 3) 4121210034_devi@pknstan.ac.id, Politeknik Keuangan Negara STAN \\ 4) ferry.irawan@pknstan.ac.id, Politeknik Keuangan Negara STAN* \\ *penulis korespondensi
}

Asyifa Tiara Ardin ${ }^{1)}$; Camelia Nur Adiningsih ${ }^{2)}$; Devi Rifqiyani Sofyan ${ }^{3)}$; Ferry Irawan ${ }^{4 *}$

\begin{abstract}
The government's policy during the Covid-19 pandemic to provide social assistance funds taken from the State Budget, resulted in a deficit and taxes as the main instrument in supporting the state budget must play a multidimensional role. On the one hand, taxes are required to achieve the tax revenue target so that our APBN is healthy, but on the other hand, it must be sensitive and responsive in the economy. The government anticipates the worst possible scenarios for the state budget, thus implementing extraordinary measures to speed up the state budget recovery. Starting from this, tax reform is crucial. Tax governance must be better. One of them is Law Number 7 of 2021 concerning the harmonization of tax regulations. The Voluntary Disclosure Program (PPS) is one of the new provisions contained in Law Number 7 of 2021 concerning Harmonization of Tax Regulations. This program aims to improve voluntary taxpayer compliance which is carried out based on the principles of simplicity, legal certainty, and expediency. The data analysis technique used in this research is normative juridical which is aimed at written regulations or other legal materials. Normative legal research refers to various secondary legal materials, namely an inventory of various legal regulations, journals, and other written works, as well as related news articles. The purpose of this study is to obtain an overview of taxpayer compliance in the voluntary disclosure program from the perspective of state administrative law. Not many studies have been conducted to investigate the relationship between state administrative law and taxpayer compliance. The results showed that the procedure carried out by the tax authorities in order to improve tax compliance through voluntary disclosure program activities is one of the implementations of state administrative law.
\end{abstract}

Keywords: Administration law, tax compliance, Voluntary Disclosure Program

\begin{abstract}
Abstrak
Kebijakan pemerintah saat pandemi Covid-19 untuk menyediakan dana bantuan sosial yang diambil dari APBN, mengakibatkan defisit dan pajak sebagai instrumen utama dalam penyokong APBN negara harus melakukan peran multidimensi. Di satu sisi pajak diminta untuk mencapai target penerimaan pajak agar APBN kita sehat, tapi di sisi lain harus peka dan responsif dalam perekonomian. Pemerintah mengantisipasi berbagai kemungkinan terburuk bagi APBN, sehingga menerapkan langkah yang luar biasa untuk melakukan pemulihan APBN dengan cepat. Berawal dari hal tersebut, maka reformasi pajak menjadi krusial. Tata kelola pajak harus menjadi lebih baik. Salah satunya adalah UU Nomor 7 Tahun 2021 tentang harmonisasi peraturan perpajakan. Program Pengungkapan Sukarela (PPS) menjadi salah satu ketentuan baru yang dimuat di dalam UU Nomor 7 Tahun 2021 tentang Harmonisasi Peraturan Perpajakan. Program ini bertujuan untuk meningkatkan kepatuhan sukarela wajib pajak yang diselenggarakan berdasarkan asas kesederhanaan, kepastian hukum, serta kemanfaatan. Teknik analisis data yang digunakan dalam penelitian ini adalah yuridis normatif yang ditujukan pada peraturan tertulis atau bahan hukum lain. Penelitian hukum normatif mengacu pada berbagai bahan hukum sekunder, yaitu inventarisasi berbagai peraturan hukum, jurnal-jurnal, dan karya tulis lainnya, serta artikel-artikel berita terkait. Tujuan penelitian adalah untuk memperoleh gambaran mengenai kepatuhan wajib pajak dalam program pengungkapan sukarela dari perspektif hukum administrasi negara. Belum banyak penelitian yang dilakukan untuk menginvestigasi kaitan hukum administrasi negara dengan kepatuhan wajib pajak. Hasil penelitian menunjukkan bahwa prosedur yang dilakukan oleh fiskus dalam rangka meningkatkan kepatuhan pajak melalui kegiatan program pengungkapan sukarela merupakan salah satu penerapan hukum administrasi negara.
\end{abstract}

Kata Kunci: Hukum Administrasi Negara, Kepatuhan Pajak, Program Pengungkapan Sukarela

\section{PENDAHULUAN}

Di era pandemi covid-19, pemerintah tentu membutuhkan dana yang sangat besar dalam rangka menyediakan bantuan sosial yang saat ini masih ditopang dengan APBN (Silalahi \& Ginting, 2020). Efeknya, defisit APBN melebar di atas ambang batas yang tadinya 
diperbolehkan oleh undang-undang keuangan negara. Pajak sebagai instrumen utama dalam penyokong APBN negara, harus melakukan peran multidimensi. Di satu sisi Direktorat Jenderal Pajak diminta untuk mencapai target penerimaan pajak agar APBN kita sehat dan segera pulih. Tantangan bagi pajak adalah harus melakukan penerimaan, tapi di sisi lain harus peka dan responsif dalam perekonomian. Selain itu, berbekal dari latar belakang untuk mengantisipasi berbagai kemungkinan terburuk bagi APBN, maka pemerintah perlu menerapkan langkah yang luar biasa untuk melakukan pemulihan APBN dengan cepat. Berawal dari hal tersebut, maka reformasi pajak menjadi krusial. Tata kelola pajak harus menjadi lebih baik. Salah satunya adalah Undang-Undang Nomor 7 Tahun 2021 tentang Harmonisasi Peraturan Perpajakan.

Program Pengungkapan Sukarela (PPS) menjadi salah satu ketentuan baru yang dimuat di dalam Undang-Undang Nomor 7 tahun 2021 tentang Harmonisasi Peraturan Perpajakan (UU HPP). Melalui PPS, wajib pajak dapat mengungkapkan harta bersih yang belum atau kurang diungkapkan dalam surat pernyataan sebagaimana dimaksud dalam Undang-Undang tentang Pengampunan Pajak (UU PP), sepanjang belum ditemukannya data dan/atau informasi mengenai harta dimaksud (Hasanah et al., 2021). Program ini bertujuan untuk meningkatkan kepatuhan sukarela wajib pajak dan diselenggarakan berdasarkan asas kesederhanaan, kepastian hukum, serta kemanfaatan. Target dari produk hukum ini adalah pengungkapan sukarela wajib pajak. Sehingga yang menjadi fokus utama adalah kepatuhan sukarela agar nantinya wajib pajak bisa masuk dalam sistem perpajakan yang telah dibuat pemerintah.

Dalam pelaksanaan hukum perpajakan di Indonesia, juga terdapat peran penting dari hukum administrasi negara (HAN). Hubungan hukum perpajakan terjadi apabila terjadi peristiwa hukum pajak, maka pada saat itulah terjadi hubungan hukum pajak antar subjek pajak dan subjek pajak dengan objeknya. HAN disini berfungsi sebagai sarana preventif agar wajib pajak tidak melanggar norma-norma dan ketentuan-ketentuan hukum perpajakan (Elisa, 2021).

Kesadaran masyarakat membayar pajak masih belum mencapai tingkat sebagaimana yang diharapkan. Umumnya masyarakat masih sinis dan kurang percaya terhadap keberadaan pajak karena masih merasa sama dengan upeti, memberatkan, pembayarannya sering mengalami kesulitan, ketidakmengertian masyarakat apa dan bagaimana pajak, dan merasa ribet mengenai perhitungan dan pelaporannya. Namun, masih ada upaya yang dapat dilakukan sehingga masyarakat sadar sepenuhnya untuk membayar pajak dan ini bukan sesuatu yang mustahil terjadi. Ketika masyarakat memiliki kesadaran maka membayar pajak akan dilakukan secara sukarela bukan keterpaksaan (Purnamasari \& Oktaviani, 2020).

Wajib pajak yang dulu pernah mengikuti tax amnesty diharapkan dapat meningkatkan kepatuhan pajaknya (Karnedi \& Hidayatulloh, 2019). Di sisi lain, sangat mungkin masih ada yang belum sepenuhnya mengungkapkan harta yang dimilikinya sampai saat ini. Jika ini terjadi maka nanti wajib pajak tersebut bisa dikenai sanksi yang besar bahkan ditambah sanksi $200 \%$. Rendahnya kesadaran masyarakat inilah yang melahirkan sikap ketidakpatuhan. Sehingga Pemerintah mengadakan program dengan memberikan kesempatan kepada wajib pajak untuk secara sukarela melaksanakan kewajiban perpajakannya dengan baik mengungkapkan hartanya.

Pentingnya membangun kesadaran, kepedulian dan kepatuhan wajib pajak berkorelasi secara dengan pencapaian target penerimaan pajak (Muhammad \& Sunarto, 2018) Meski demikian, dukungan seluruh lapisan masyarakat sangat dibutuhkan. Dalam membangun kesadaran dan kepedulian sukarela wajib pajak, diperlukan landasan pemikiran bahwa kesadaran membayar pajak harus datang dari diri sendiri dan dipupuk sejak masa kanak-kanak (Valianti et al., 2021). Salah satu hal yang dapat dilakukan dalam rangka membangun kesadaran serta sukarela wajib pajak adalah dengan melakukan sosialisasi dengan cara menanamkan pengertian dan pemahaman tentang pajak yang bisa diawali dari lingkungan keluarga sendiri yang terdekat, melebar kepada tetangga, lalu dalam forum-forum tertentu dan ormas-ormas 
tertentu. Dengan tingginya intensitas informasi yang diterima oleh masyarakat, maka dapat secara perlahan merubah mindset masyarakat tentang pajak ke arah yang positif. Jika wajib pajak memiliki kesadaran dalam mengungkapkan jumlah pajaknya, maka fiskus atau pemungut pajak bisa melanjutkan tugasnya dengan mudah dan hukum dapat berjalan sebagaimana mestinya. Penelitian ini bertujuan utuk menganalisis kepatuhan wajib pajak dalam program pengungkapan sukarela dari perspektif hukum administrasi negara.

\section{KAJIAN PUSTAKA}

Menurut (Anggara, 2018) Hukum Administrasi Negara adalah aturan yang menguasai berbagai cabang kegiatan yang isinya berupa ketentuan mengenai campur tangan negara dan alat-alat perlengkapan negara dalam lingkungan swasta, juga menentukan organisasi kekuasaan dan tugas-tugas pejabat administrasi. Hukum administrasi negara juga disebut hukum tata pemerintahan. Hukum ini dibuat untuk mengatur tugas pejabat administrasi negara dalam menghadapi masyarakat, pada sisi lain hukum ini dapat digunakan masyarakat untuk mempengaruhi dan memperoleh perlindungan dari pemerintah. Seiring berkembangnya zaman ruang lingkup hukum administrasi negara semakin menjadi luas dan kompleks karena kecenderungan negara turut campur tangan dalam kehidupan masyarakat. Fungsi hukum administrasi negara meliputi menjamin kepastian hukum, menjamin keadilan hukum, dan sebagai pedoman dan ukuran. Sebagai pedoman, artinya sebagai petunjuk arah perilaku manusia. Sedangkan sebagai ukuran artinya untuk menilai apakah pelaksanaan pemerintahan tersebut dilakukan secara benar atau salah.

Di tahun 2021 Pemerintah menerbitkan UU HPP. Dalam UU HPP ini terdapat Program Pengungkapan Sukarela (PPS) bagi wajib pajak. Program ini bertujuan untuk meningkatkan kepatuhan sukarela wajib pajak dengan memberikan kesempatan kepada seluruh wajib pajak mengungkapkan hartanya yang belum diungkapkan. Program pengungkapan sukarela ini dilaksanakan selama 6 bulan dari tanggal 1 Januari 2022 sampai dengan 30 Juni 2022. Kebijakan program pengungkapan sukarela dicantumkan dalam UU HPP dalam rangka meningkatkan kepatuhan wajib pajak (Irawan \& Raras, 2021).

Pandemi Covid-19 telah membuat keadaan perekonomian Indonesia sangat terpuruk (Sumarni, 2020). Pada tahun 2020 penerimaan perpajakan mencapai Rp1.018,83 triliun, terkontraksi sebesar 15,51 persen dari periode yang sama pada tahun 2019 yang mencapai Rp1.312,37 triliun. Pada tahun 2021 perekonomian Indonesia mulai bangkit dilihat dari realisasi penerimaan pajak mencapai Rp1.227,53 triliun atau tumbuh 19,16 persen. Hal ini terbukti bahwa pendapatan negara melebihi target APBN maupun capaian prapandemi di tahun 2019.

Pemerintah melakukan berbagai tindakan berupa tindakan nyata dan tindakan hukum. Tindakan nyata adalah tindakan yang tidak ada hubungannya dengan hukum karena tidak menimbulkan akibat hukum sedangkan tindakan hukum adalah tindakan yang menimbulkan akibat hukum tertentu yang dimaksudkan untuk menciptakan hak dan kewajiban (Haris, 2017). Setiap orang dan pihak ketiga juga berhak dan berkewajiban untuk bertindak. Tindakan itu juga berupa tindakan hukum dan tindakan nyata. Pemerintah juga memiliki keterbatasan dalam menjalankan kewenangannya yaitu harus sesuai peraturan perundang-undangan yang berlaku (Said, 2015). Bila pejabat melaksanakan tugasnya tapi tidak sesuai dengan batasan tersebut maka pejabat tersebut tidak berwenang. Misal bila sudah ada batasan waktu, bahwa surat permohonan wajib pajak kepada Direktur Jenderal Pajak dalam jangka waktu paling lama 6 (enam) bulan sejak tanggal surat permohonan pembetulan diterima, harus memberi keputusan atas permohonan pembetulan yang diajukan wajib pajak maka apabila jangka waktu telah lewat, tetapi Direktur Jenderal Pajak tidak memberi suatu keputusan, permohonan pembetulan yang diajukan tersebut dianggap dikabulkan (Simandjuntak, 2014). 


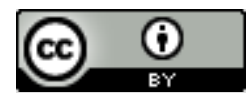

\section{METODE}

Penelitian ini menggunakan pendekatan kualitatif dengan tujuan untuk dapat memperoleh makna mendalam atas objek yang diteliti (Rukajat, 2018). Dalam penelitian ini, hal pertama yang dilakukan adalah membuat pendahuluan yang berisi permasalahan yang akan diteliti, wawasan, dan rencana pemecahan masalah, serta rumusan tujuan penelitian. Selanjutnya adalah membuat kajian pustaka yang berisi rangkuman kajian teoritik yang berkaitan dengan masalah Hukum Administrasi Negara dengan Program Pengungkapan Sukarela. Setelah itu, menuliskan metode penelitian yang digunakan dalam menyelesaikan penelitian. Metode penelitian berisi empat hal, yaitu rancangan penelitian, populasi dan sampel, teknik pengumpulan data, dan teknik analisis data. Setelah itu, membuat hasil dan pembahasan yang merupakan hal utama dalam penelitian. Hal yang terakhir adalah penutup berisi kesimpulan dan saran. Berikut skema rancangan penelitian untuk meninjau Hukum Administrasi Negara terhadap kepatuhan wajib pajak dalam Program Pengungkapan Sukarela:

\section{Gambar 1. Skema Rancangan Penelitian}

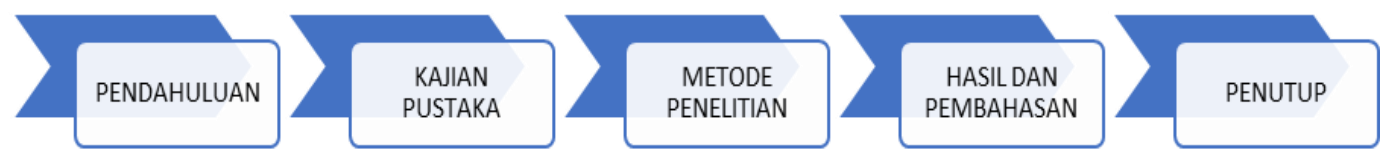

Sumber: olahan Penulis

Teknik pengumpulan data adalah metode yang digunakan untuk mengumpulkan datadata yang berkaitan dengan masalah yang sedang diteliti. Dalam penelitian ini data yang digunakan adalah data sekunder yang diperoleh dari studi pustaka (library research) yang bertujuan untuk mendapatkan konsep, teori, serta informasi-informasi dan pemikiran konseptual, baik berupa peraturan perundang-undangan dan karya ilmiah lainnya. Data sekunder yang digunakan dalam penulisan tersebut merupakan bahan hukum primer yang terdiri dari peraturan di bidang hukum tentang pemungutan dan pembayaran pajak, bahan hukum sekunder yang mencakup dokumen-dokumen resmi, dan bahan hukum tersier yang memberikan petunjuk atau penjelasan bermakna terhadap bahan hukum primer dan bahan hukum sekunder yakni kamus hukum dan Kamus Besar Bahasa Indonesia.

Teknik analisis data yang digunakan dalam penelitian ini adalah yuridis normatif, maksudnya suatu penelitian yang dilakukan hanya ditujukan pada peraturan yang tertulis atau bahan hukum lain. Penelitian hukum normatif sendiri mengacu pada berbagai bahan hukum sekunder yaitu inventarisasi berbagai peraturan hukum, jurnal-jurnal dan karya tulis lainnya, serta artikel-artikel berita terkait.

Hasil dan pembahasan dalam penelitian ini bertujuan untuk mendeskripsikan secara sistematis, faktual, dan akurat tentang kepatuhan wajib pajak dalam Program Pengungkapan Sukarela atau PPS. Program tersebut merupakan program baru yang muncul dalam Undang Undang Harmonisasi Peraturan Perpajakan atau yang biasa disingkat UU HPP. Hukum yang mengatur PPS tertulis dalam UU Nomor 7 tahun 2021 Bab V pada pasal 5 sampai 12.

Data akan dianalisis setelah data penelitian terkumpul melalui studi pustaka dengan cara mengkaji sumber tertulis seperti peraturan perundang- undangan, literatur buku maupun karya ilmiah penelitian, makalah, dan sumber-sumber lainya berupa artikel. Kemudian data penelitian tersebut dianalisis dan dihubungkan dengan teori-teori yang diperoleh dari bacaan tersebut, sehingga penulis bisa memperoleh jawaban atas permasalahan yang diteliti.

Data mengenai hukum yang diperoleh akan dianalisis secara normatif tentang kepatuhan wajib pajak dalam Program Pengungkapan Sukarela. Disebut normatif karena penelitian ini berasal dari peraturan-peraturan yang ada sebagai norma hukum positif. 
Penelitian dilakukan untuk mendapatkan pemahaman setelah melakukan analisis terhadap kenyataan sosial yang menjadi fokus penelitian. Harapan di akhir penelitian adalah untuk mencapai kejelasan masalah yang akan dibahas.

\section{HASIL DAN PEMBAHASAN}

\section{Kesukarelaan Wajib Pajak}

Permasalahan yang dibahas mengenai fiskus sebagai pemungut pajak memiliki keterkaitan dengan hukum administrasi negara, khususnya untuk mencegah wajib pajak supaya tidak melanggar norma-norma dan ketentuan-ketentuan hukum perpajakan. Wajib pajak diharapkan memiliki kesadaran diri untuk melaporkan besarnya pajak yang harus dibayar. Penelitian diarahkan untuk mengetahui seberapa besar kesadaran diri yang telah wajib pajak lakukan dalam mengungkapkan besarnya pajak yang harus dibayar saat fiskus tidak ikut menghitung besaran pajaknya, kejujuran wajib pajak diuji dalam program ini.

Menurut (Tahar \& Rachman, 2014) kepatuhan mengenai perpajakan merupakan tanggung jawab kepada Tuhan, bagi pemerintah, dan rakyat sebagai wajib pajak untuk memenuhi semua kegiatan kewajiban perpajakan dan melaksanakan hal perpajakannya. Kepatuhan wajibpPajak merupakan perilaku yang didasarkan pada kesadaran seorang wajib pajak terhadap kewajiban perpajakannya dengan tetap berlandaskan pada peraturan perundangundangan yang telah ditetapkan. Sehingga, kepatuhan wajib pajak adalah suatu sikap Wajib Pajak yang didasari oleh kerelaan dan kesediaan dalam memenuhi kewajiban perpajakannya sesuai dengan ketentuan perpajakan yang berlaku, misalnya dalam hal melaporkan, menghitung, dan membayar pajaknya dengan tepat waktu. Kepedulian dan kesadaran sukarela Wajib Pajak sangat sulit untuk diwujudkan apabila dalam definisi 'pajak' tidak terdapat frase "yang dapat dipaksakan" dan "yang bersifat memaksa." Dari frase ini menunjukkan bahwa membayar pajak bukan semata-mata perbuatan sukarela atau karena suatu kesadaran. Frase ini memberikan pemahaman serta pengertian bahwa masyarakat dituntut untuk melaksanakan kewajiban kenegaraan dengan membayar pajak secara sukarela serta penuh kesadaran sebagai aktualisasi semangat gotong-royong atau solidaritas nasional dalam menciptakan perekonomian nasional.

\section{Gambar 2. Ilustrasi Ajakan untuk Membayar Pajak}

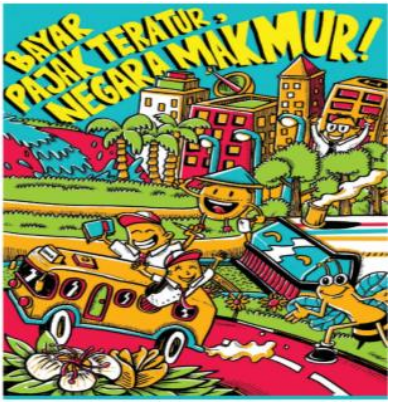

Sumber: Materi Terbuka Kesadaran Pajak untuk Perguruan Tinggi

Gambar 2 di atas memiliki makna bahwa dengan membayar pajak teratur akan memberikan dampak baik bagi negara, yaitu kemakmuran. Pajak juga diatur oleh hukum dan merupakan bagian dari konsep hukum secara umum. Hukum pajak didefinisikan sebagai keseluruhan dari peraturan-peraturan yang meliputi wewenang pemerintah untuk mengambil kekayaan seseorang dan menyerahkan kembali kepada masyarakat melalui kas negara, sehingga hukum pajak tersebut merupakan hukum publik yang mengatur hubungan negara dan orang-orang atau badan-badan hukum yang berkewajiban membayar pajak (Candra \& Sundarta, 2007). Hukum pajak mengatur kontrak sosial antara negara dan warganya sehingga proses pelaksanaan hak serta kewajiban perpajakan dan penegakan hukumnya harus 
berdasarkan hukum melalui peraturan perundang-undangan. Peraturan perundang-undangan mengenai pajak dimulai dari Pasal 23A UUD Tahun 1945 yang berbunyi "Pajak dan pungutan lain yang bersifat memaksa untuk keperluan negara diatur dengan undang-undang". Berdasarkan Pasal 23A UUD Tahun 1945 tersebut, pemerintah membuat peraturan perundangundangan untuk mengatur lebih lanjut mengenai pelaksanaan hak dan kewajiban perpajakan sebagaimana telah dijelaskan pada Bab VIII.

\section{Gambar 3. Struktur Organisasi Kementerian Keuangan}

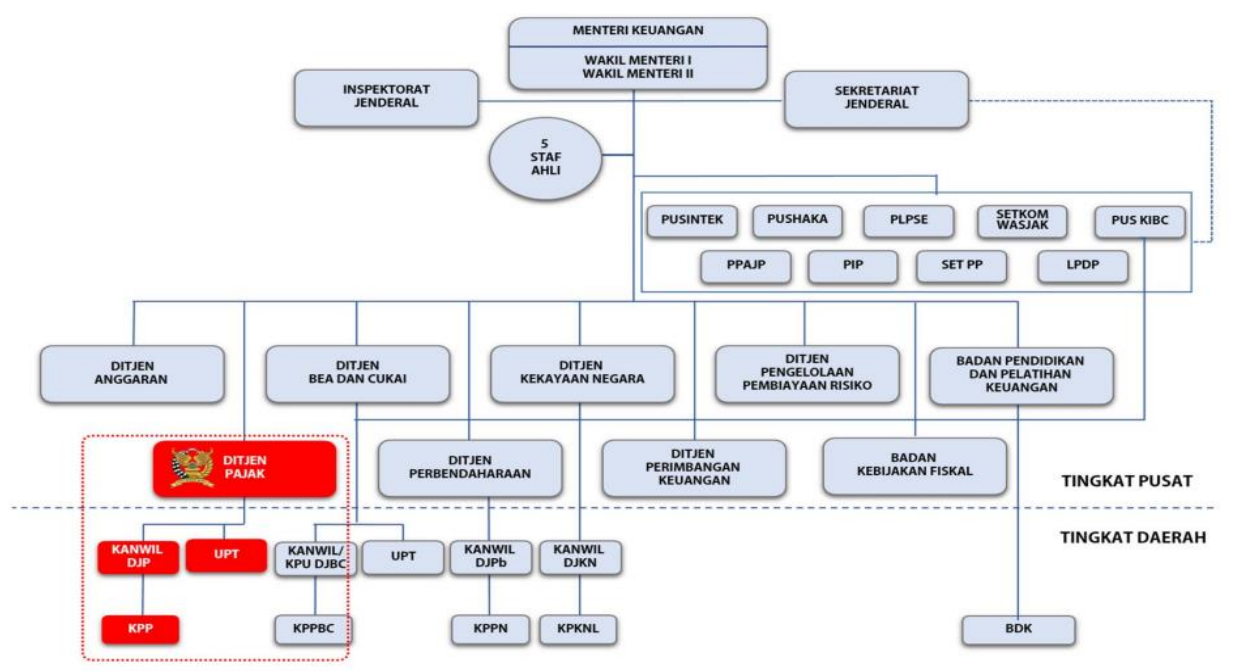

Sumber: Materi Terbuka Kesadaran Pajak untuk Perguruan Tinggi

Gambar 3 merupakan struktur organisasi kementerian keuangan selaku pengatur dan pengelola pajak. Seperti yang diketahui, terdapat dua tujuan pajak, yaitu budgetair dan reguleren. Proses penegakan hukum pajak juga bertujuan sama, yaitu untuk memenuhi penerimaan negara dan untuk mengatur agar warga negara bersedia secara sukarela membayar pajak. Dengan adanya penegakan hukum pajak, negara mengharapkan timbulnya kesadaran dan kesukarelaan dari warga negara yang patuh, serta bagi warga negara yang tidak patuh akan dikenakan sanksi sesuai dengan kadar ketidakpatuhannya. Penegakan hukum ini akan lebih efektif apabila pengawasannya tidak hanya dilakukan oleh aparatur pemerintah saja, tetapi juga pengawasan bersama dari masyarakat. Pengawasan bersama ini dapat dilakukan dengan cara saling mengingatkan akan kewajiban perpajakan dari masing-masing individu di masyarakat.

Kesadaran wajib pajak masih belum mencapai tingkat sebagaimana yang diharapkan. Namun masih ada upaya yang dapat dilakukan sehingga wajib pajak dapat sadar sepenuhnya untuk membayar pajak dan ini bukan sesuatu yang mustahil terjadi. Ketika wajib pajak memiliki kesadaran maka membayar pajak akan dilakukan secara sukarela bukan keterpaksaan. Kesadaran membayar pajak ini tidak hanya memunculkan sikap patuh, taat, dan disiplin semata tetapi diikuti sikap kritis juga. Semakin maju masyarakat dan pemerintahannya, maka semakin tinggi kesadaran membayar pajaknya namun tidak hanya berhenti sampai di situ justru mereka semakin kritis dalam menyikapi masalah perpajakan, terutama terhadap materi kebijakan di bidang perpajakannya, misalnya penerapan tarifnya, mekanisme pengenaan pajaknya, regulasinya, benturan praktek di lapangan, dan perluasan subjek dan objeknya.

Apalagi manfaat pajak yang mereka bayar nantinya dapat dinikmati apabila sudah memenuhi target penerimaan negara. Kenikmatan yang dimaksud ada dalam berbagai bidang, seperti kesehatan, pendidikan, sosial maupun sarana dan prasarana transportasi yang cukup maju. Selain itu, pelayanan medis gratis, sekolah murah, jaminan sosial, dan alat-alat transportasi modern menjadi bukti pemerintah mengelola dana pajak dengan baik. Dengan digalakannya kesadaran akan pajak ini diharapkan Indonesia akan menuju kesejahteraan yang 
selama ini diharapkan. Slogan "LUNASI PAJAKNYA AWASI PENGGUNAANNYA" tidak hanya suara dan gaungnya semata yang nyaring namun bisa benar-benar terwujudkan bahwa pajak menjadi pendapatan utama negara yang diperuntukkan dan dikelola dengan transparan dan akuntabel bagi kepentingan masyarakatnya sendiri.

Peran pajak sangat besar dalam membiayai berbagai pengeluaran negara khususnya dalam pembangunan. Apalagi jika masyarakat sebagai wajib pajak sadar akan kewajibannya dalam membayar pajak sehingga pembangunan dapat dioptimalkan. Namun, sampai saat ini dapat dilihat bahwa kepatuhan membayar pajak oleh wajib pajak masih rendah, sebagaimana yang disampaikan oleh Direktur Penyuluhan, Pelayanan dan Hubungan Masyarakat Ditjen Pajak Hestu Yoga Saksama bahwa kepatuhan pajak masyarakat Indonesia dapat dilihat dari tingkat tax ratio yang masih 10,3\% pada tahun 2017. Apabila dikaitkan dengan teori kepatuhan hukum, maka kesadaran hukum dapat mempengaruhi tingkat kepatuhan hukum masyarakat (Usman, 2014). Sama halnya dengan kepatuhan masyarakat terhadap pajak sangat dipengaruhi oleh kesadaran masyarakatnya. Oleh karena itu, sangat penting untuk meningkatkan kesadaran pajak bagi warga negara Indonesia. Pandangan bahwa membayar pajak merupakan wujud kecintaan kepada tanah air sebagaimana dianut oleh warga Jepang juga rasa tanggung jawab untuk berkontribusi mewujudkan kesejahteraan sebagaimana yang dianut warga Australia harus ditanamkan dalam diri warga negara Indonesia.

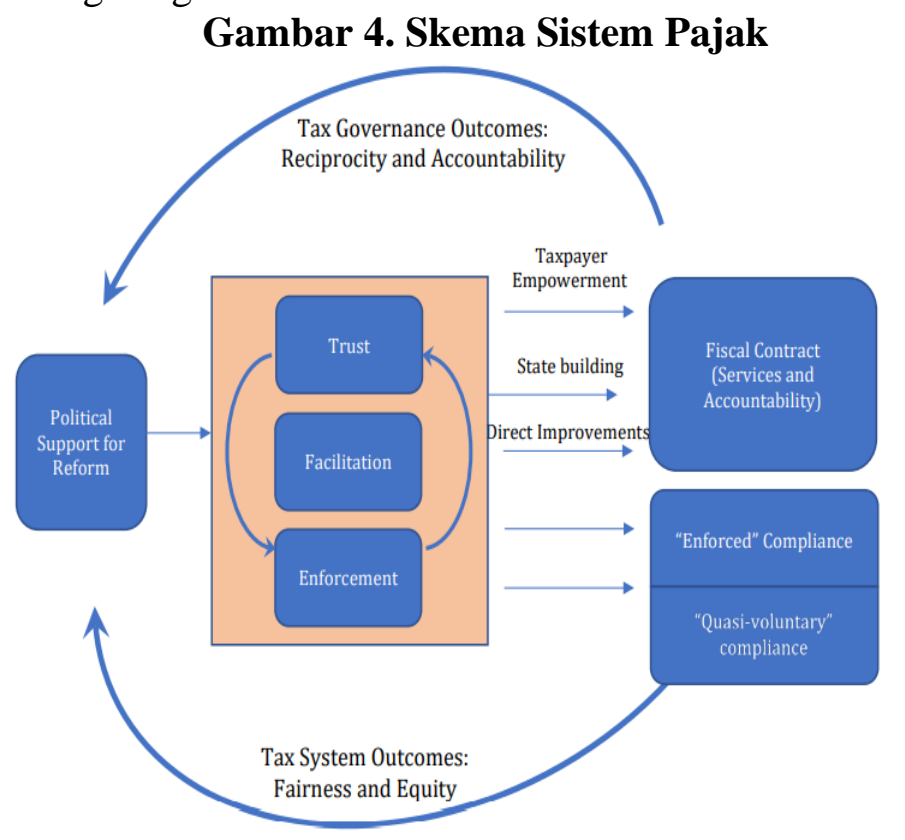

Sumber: World Bank (2019)

Prichard et al. (2019) menyatakan bahwa menggabungkan investasi komplementer dalam penegakan hukum, fasilitasi, dan kepercayaan tidak hanya dapat memperkuat "kepatuhan yang dipaksakan" tetapi juga dapat mendorong "kepatuhan semu sukarela", menciptakan kondisi yang kondusif untuk memperkuat fiskal kontrak, dan menghasilkan dukungan politik yang berkelanjutan untuk reformasi. Pada Gambar 4 bisa dilihat bahwa dengan dukungan politik dapat meningkatkan kepercayaan masyarakat sehingga hal ini mendorong wajib pajak menjadi patuh dan sadar pajak. Terdapat dua kepercayaan berbeda yang dicerminkan yaitu keadilan dan kesetaraan sistem pajak, dan timbal balik dan akuntabilitas dalam sistem. Dimana pembayar pajak melihat keuntungan yang terlihat sehingga mereka akan lebih bersedia untuk patuh membayar pajak. 


\section{Dukungan Pemerintah dalam PPS}

Dukungan pemerintah dalam meningkatkan administrasi negara diharapkan akan mampu mengatasi masalah-masalah dalam perpajakan dan merealisasi peraturan perpajakan. Jika administrasi negara ini dapat mengatasi masalah-masalah yang ada, maka tax ratio akan meningkat sehingga mempengaruhi kepatuhan sukarela wajib pajak. De Jantscher (1996) dalam (Masyhur, 2013) mengemukakan bahwa "keadilan merupakan salah satu elemen yang dapat membantu meningkatkan kepercayaan masyarakat atas sistem perpajakan dan selanjutnya meningkatkan kepatuhan sukarela masyarakat pembayar pajak." Setelah memperoleh kepercayaan dan dukungan masyarakat dapat dikatakan administrasi negara ini sudah sehat.

Untuk mendorong Program Pengungkapan Sukarela (PPS) pemerintah juga harus meningkatkan pemahaman pajak kepada masyarakat supaya mempengaruhi kepatuhan sukarela wajib pajak. Pemerintah dapat melakukan sosialisasi kepada masyarakat agar pemahaman pajak ini dapat merata ke seluruh Indonesia. Program Pengungkapan Sukarela ini mengharapkan wajib pajak untuk jujur dalam hal pelaporan jumlah peredaran usaha sesuai dengan kondisi yang sebenarnya karena telah diberikan kepercayaan penuh oleh pemerintah. Selain itu sanksi pajak juga berpengaruh dalam kepatuhan sukarela wajib pajak ini. Hasil studi Siregar (2017) menunjukkan semakin tinggi nilai variabel sanksi pajak semakin tinggi tingkat kepatuhan wajib pajak dalam membayar pajak. Indikator yang digunakan dalam penelitian ini berupa sanksi administrasi dan sanksi pidana mampu meningkatkan kepatuhan wajib pajak dalam membayarkan pajak. Hasil dari penelitian ini juga sejalan dengan penelitian As'ari \& Erawati (2018) yang menyatakan bahwa sanksi pajak berpengaruh signifikan terhadap kepatuhan wajib pajak. Jika kepatuhan sukarela wajib pajak ini tidak terjadi maka akan berdampak pada tidak efektifnya penerimaan pajak sehingga mengakibatkan terhambatnya pembangunan sarana dan prasarana Indonesia.

Banyak manfaat yang akan diperoleh WP, di antaranya, terbebas dari sanksi administratif dan perlindungan data bahwa data harta yang diungkapkan tidak dapat dijadikan sebagai dasar penyelidikan, penyidikan, dan/atau penuntutan pidana terhadap WP. PPS diselenggarakan dengan asas kesederhanaan, kepastian hukum, dan kemanfaatan untuk meningkatkan kepatuhan sukarela WP sebelum penegakan hukum dilakukan dengan basis data dari pertukaran data otomatis (AEoI) dan data ILAP yang dimiliki DJP. Dalam rangka mendorong kepatuhan sukarela wajib pajak, RUU HPP ini menerapkan program pengungkapan sukarela. Berdasarkan teori tentang kepatuhan yang didukung penelitian empirik di berbagai negara, upaya memfasilitasi itikad baik wajib pajak yang ingin jujur dan terbuka masuk ke dalam sistem administrasi pajak dapat meningkatkan kepatuhan pajak sukarela di masa mendatang. Namun program ini tetap harus diikuti upaya pengawasan dan penegakan hukum yang adil dan konsisten, serta memberikan perlakuan yang adil dan pelayanan yang baik terhadap wajib pajak yang sudah patuh dan berisiko rendah. Dalam konteks inilah Program Pengungkapan Sukarela (PPS) merupakan kebijakan yang tidak dapat dipisahkan dari narasi besar reformasi perpajakan yang telah kami elaborasi sebelumnya.

\section{Perbandingan dengan Kebijakan Program Pengampunan Pajak}

Untuk menjamin pemenuhan rasa keadilan dan memfasilitasi wajib pajak yang sungguh-sungguh ingin patuh, prinsip umum yang menjadi komitmen pemerintah dan DPR adalah besaran tarif $\mathrm{PPh}$ final yang lebih tinggi dibandingkan tarif tebusan saat program pengampunan pajak. Program yang akan berjalan selama 6 bulan (1 Januari 2022 s/d 30 Juni 2022) ini akan memberikan kesempatan kepada WP untuk mengungkapkan secara sukarela atas harta yang belum dilaporkan dalam program pengampunan pajak 2016/2017 maupun dalam SPT Tahunan 2020, yang terdiri dari 2 kebijakan. 


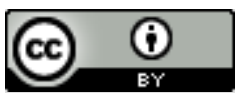

Kebijakan I

Peserta Program Pengampunan Pajak Tahun 2016 (untuk Orang Pribadi dan Badan) dapat mengungkapkan harta bersih yang belum dilaporkan pada saat Program Pengampunan Pajak, dengan membayar PPh Final sebesar:

a. $11 \%$ untuk harta di luar negeri yang tidak direpatriasi ke dalam negeri.

b. $8 \%$ untuk harta di luar negeri yang direpatriasi dan harta di dalam negeri.

c. $6 \%$ untuk harta di luar negeri yang direpatriasi dan harta di dalam negeri, yang diinvestasikan dalam Surat Berharga Negara (SBN) dan hilirisasi Sumber Daya Alam (SDA) dan energi terbarukan.

Kebijakan II

Wajib Pajak Orang Pribadi (peserta Program Pengampunan Pajak maupun non peserta Program Pengampunan Pajak) dapat mengungkapkan harta bersih yang berasal dari penghasilan tahun 2016 s/d 2020, namun belum dilaporkan pada SPT Tahunan PPh Tahun Pajak 2020, dengan membayar PPh Final sebesar:

a. $18 \%$ untuk harta di luar negeri yang tidak direpatriasi ke dalam negeri.

b. $14 \%$ untuk harta di luar negeri yang direpatriasi dan harta di dalam negeri.

c. $12 \%$ untuk harta di luar negeri yang direpatriasi dan harta di dalam negeri, yang diinvestasikan dalam Surat Berharga Negara (SBN) dan hilirisasi Sumber Daya Alam (SDA) dan energi terbarukan. Berdasarkan data pasca Pengampunan Pajak Tahun 2016, kepatuhan pelaporan SPT tahunan maupun jumlah pembayaran pajak para peserta

Pengampunan Pajak pada tahun 2017 dan setelahnya mengalami peningkatan kepatuhan cukup signifikan, dan berharap program pengungkapan sukarela ini juga akan memberikan efek positif yang sama dalam rangka meningkatkan kepatuhan kewajiban perpajakan wajib pajak, karena juga didukung seperangkat aturan tentang keterbukaan informasi dan reformasi sistem administrasi perpajakan yang semakin mumpuni dalam melakukan pengawasan.

Dampak penerapan UU HPP terhadap perekonomian dan masyarakat menjadi perhatian pemerintah. Melalui penerimaan negara yang membaik, belanja negara untuk mengurangi kemiskinan dan mendorong akselerasi pemulihan ekonomi dapat ditingkatkan. Dengan demikian penerapan UU HPP bersama dengan reformasi fiskal dan belanja negara yang makin terarah dan tepat sasaran diharapkan akan menghasilkan pemulihan ekonomi yang makin kuat, dan pengurangan kemiskinan yang semakin cepat. Reformasi perpajakan adalah suatu mata rantai tak terpisahkan dari reformasi perpajakan yang telah dijalankan. Pandemi Covid-19 menjadi momentum untuk mempercepat proses reformasi perpajakan untuk menata ulang sistem perpajakan Indonesia agar mampu mengadopsi praktik-praktik terbaik dan mengantisipasi dinamika sosial ekonomi di masa yang akan datang.

\section{Reformasi Perpajakan melalui UU HPP}

Reformasi perpajakan dilakukan baik di dalam aspek administrasi maupun aspek kebijakan. RUU HPP yang telah disepakati merupakan bagian penting dari reformasi perpajakan untuk membangun fondasi perpajakan yang adil, sehat, efektif, dan akuntabel, dalam jangka menengah/panjang, dengan tujuan untuk:

a. Meningkatkan pertumbuhan dan mendukung percepatan pemulihan perekonomian;

b. Mengoptimalkan penerimaan negara;

c. Mewujudkan sistem perpajakan yang berkeadilan dan berkepastian hukum;

d. Melaksanakan reformasi administrasi, kebijakan perpajakan yang konsolidatif, dan

perluasan basis pajak;

e. Meningkatkan kepatuhan sukarela Wajib Pajak.

Diharapkan melalui RUU HPP ini, pajak benar-benar hadir untuk mendukung rakyat dan berkontribusi dalam pemulihan ekonomi nasional serta meningkatkan keadilan di masyarakat. Program Pengungkapan Sukarela (PPS) pada Semester I Tahun 2022 dapat 
meningkatkan kontribusi penerimaan perpajakan pada APBN pada Tahun 2022 serta mendukung penyehatan kembali APBN dengan defisit maksimal 3\% pada tahun 2023. Sejalan dengan tujuan meningkatkan kesadaran pajak, maka keberadaan generasi muda yang akrab disapa generasi milenial menjadi sangat penting untuk mendukung tujuan tersebut. Generasi milenial adalah generasi yang lahir pada tahun 1980 - 2000an, dimana usianya saat ini mencapai 17-37 tahun yang merupakan usia produktif. Sebagaimana data menunjukkan bahwa pada tahun 2045 Indonesia mengalami bonus demografi yaitu penduduk usia produktif mencapai angka mayoritas di Indonesia. Oleh karena itu, bonus demografi yang dipenuhi oleh generasi milenial ini harus dioptimalkan untuk mendukung budaya sadar pajak yang diharapkan dapat menciptakan wajib pajak yang patuh pajak.

\section{PENUTUP \\ Simpulan}

Fiskus sebagai pemungut pajak memiliki keterkaitan dengan pelaksanaan hukum administrasi negara, khususnya untuk mencegah wajib pajak supaya tidak melanggar normanorma dan ketentuan-ketentuan hukum perpajakan. Program Pengungkapan Sukarela (PPS) menuntut masyarakat untuk melaksanakan kewajiban kenegaraan dengan membayar pajak secara sukarela serta penuh kesadaran sebagai aktualisasi semangat gotong-royong atau solidaritas nasional dalam menciptakan perekonomian nasional. PPS dikatakan sukarela karena dalam program ini sikap wajib pajak harus didasari oleh kerelaan dan kesediaan dalam memenuhi kewajiban perpajakannya sesuai dengan ketentuan perpajakan yang berlaku, misalnya dalam hal melaporkan, menghitung, dan membayar pajaknya dengan tepat waktu.

Proses pelaksanaan hak serta kewajiban perpajakan dan penegakan hukum harus berdasarkan hukum melalui peraturan perundang-undangan. Hukum pajak di negara kita dimulai dari Pasal 23A UUD Tahun 1945 yang berbunyi "Pajak dan pungutan lain yang bersifat memaksa untuk keperluan negara diatur dengan undang-undang". Proses penegakan hukum pajak bertujuan untuk memenuhi penerimaan negara dan untuk mengatur agar warga negara bersedia secara sukarela membayar pajak. Dengan adanya penegakan hukum pajak, negara mengharapkan timbulnya kesadaran dan kesukarelaan dari warga negara yang patuh, serta bagi warga negara yang tidak patuh, mereka dikenakan sanksi sesuai dengan kadar ketidakpatuhannya. Penegakan hukum ini akan lebih efektif apabila pengawasannya tidak hanya dilakukan oleh aparatur pemerintah saja, tetapi juga pengawasan bersama dari masyarakat. Pengawasan bersama ini dapat dilakukan dengan cara saling mengingatkan akan kewajiban perpajakan dari masing-masing individu di masyarakat.

Sampai saat ini kesadaran wajib pajak masih belum mencapai tingkat sebagaimana yang diharapkan. Namun masih ada upaya yang dapat dilakukan sehingga wajib pajak dapat sadar sepenuhnya untuk membayar pajak dan ini bukan sesuatu yang mustahil terjadi. Semakin maju masyarakat dan pemerintahannya, maka semakin tinggi kesadaran membayar pajaknya dan semakin kritis dalam menyikapi masalah perpajakan, terutama terhadap materi kebijakan di bidang perpajakannya, misalnya penerapan tarifnya, mekanisme pengenaan pajaknya, regulasinya, benturan praktek di lapangan dan perluasan subjek dan objeknya.

Program tax amnesty pada Tahun 2017 meningkatkan kepatuhan wajib pajak secara umum. Untuk itu pada program pengungkapan sukarela Tahun 2022 ini juga dapat memberikan efek yang serupa. Direktorat Jenderal Pajak juga telah meningkatkan kualitas infrastruktur yang lebih memadai dalam rangka melaksanakan pengawasan. Diharapkan melalui RUU HPP ini, pajak hadir untuk mendukung rakyat dan berkontribusi dalam pemulihan ekonomi nasional serta meningkatkan keadilan di masyarakat serta memperbaiki postur APBN untuk mengurangi defisit. 


\section{Saran}

UU Harmonisasi Perpajakan ini diharapkan dapat meningkatkan kesadaran wajib pajak untuk mengungkapkan pajaknya secara sukarela sehingga tujuan penerimaan pajak yang optimal melalui peningkatan kepatuhan dapat tercapai. Peneliti selanjutnya dapat menggunakan pendekatan kuantitatif untuk mengukur efektifitas program pengungkapan sukarela. Selain itu, studi berikutnya juga dapat mengkaji sejauh mana penerapan asas-asas hukum administrasi negara dilaksanakan untuk meningkatkan kepatuhan wajib pajak.

\section{DAFTAR PUSTAKA}

Anggara, S. (2018). Hukum Administrasi Negara. CV Pustaka Setia.

As'ari, N. G., \& Erawati, T. (2018). Pengaruh Pemahaman Peraturan Perpajakan, Kualitas Pelayanan (Studi Empiris pada Wajib Pajak Orang Pribadi Kecamatan Rongkop). Jurnal Ekobis Dewantara, 1(6), 64-76. https://doi.org/10.29230/ad.v2i1.2221

Candra, A., \& Sundarta, M. I. (2007). Pelaksanaan Wewenang Direktur Jenderal Pajak Terhadap Pengurangan dan Pembatalan Ketetapan Pajak Menurut Ketentuan Umum dan Tata Cara Perpajakan ( UU KUP ). Jurnal Ilmiah Akuntansi Dan Keuangan, 28, 59-95.

Elisa, N. (2021). Tinjauan Hukum Administrasi Negara Terhadap Pembayaran Pajak. Jurnal Institusi Politeknik Ganesha Medan, 4(September), 73-79.

Haris, O. K. (2017). Good Governance (Tata Kelola Pemerintahan Yang Baik) Dalam Pemberian Izin Oleh Pemerintah Daerah Di Bidang Pertambangan. Yuridika, 30(1), 5883. https://doi.org/10.20473/ydk.v30i1.4879

Hasanah, U., Na'im, K., Elyani, E., \& Waruwu, K. (2021). Analisis Perbandingan Tax Amnesty Jilid I dan Jilid II (Program Pengungkapan Sukarela) Serta Peluang Keberhasilannya. Owner, 5(2), 706-716. https://doi.org/10.33395/owner.v5i2.565

Irawan, F., \& Raras, P. (2021). Program Pengungkapan Sukarela Dalam Rangka Meningkatkan Kepatuhan Pajak Di Masa Pandemi Covid-19. Pengmasku, 1(2), 86-93. https://doi.org/10.54957/pengmasku.v1i2.107

Karnedi, N. F., \& Hidayatulloh, A. (2019). Pengaruh Kesadaran Perpajakan, Sanksi Pajak Dan Tax Amnesty Terhadap Kepatuhan Wajib Pajak Orang Pribadi. Jurnal Profita, 12(1), 1-9. https://doi.org/10.22441/profita.2019.v12.01.001

Masyhur, H. (2013). Pengaruh Sistem Administrasi Perpajakan Modern Terhadap Kepatuhan Wajib Pajak. Jurnal Ilmu Manajemen Dan Bisnis, 04(01), 1-10.

Muhammad, A., \& Sunarto, S. (2018). Pengaruh Pemeriksaan Pajak, Penagihan Pajak, dan Kepatuhan Wajib Pajak terhadap Penerimaan Pajak Studi Kasus pada KPP Pratama Raba Bima Tahun 2012-2015. Akuntansi Dewantara, 2(1), 37-45.

Prichard, W., Custers, A., Dom, R., Davenport, S., \& Roscitt, M. (2019). Innovations in Tax Compliance Conceptual Framework. www.worldbank.org/prwp.

Purnamasari, P., \& Oktaviani, R. M. (2020). Kesadaran Membayar Pajak Memediasi Hubungan Pengetahuan Perpajakan terhadap Kemauan Membayar Pajak. Jurnal Akuntansi Dan Pajak, 21(1), 221-230.

Said, A. R. A. (2015). Division of the Central Government and the Regional Government Authority in the Autonomy Based on the Constitution 1945. Fiat Justisia Jurnal Ilmu Hukum, 9(4), 505-530.

Silalahi, D. E., \& Ginting, R. R. (2020). Strategi Kebijakan Fiskal Pemerintah Indonesia Untuk Mengatur Penerimaan dan Pengeluaran Negara Dalam Menghadapi Pandemi Covid-19. Jesya (Jurnal Ekonomi \& Ekonomi Syariah), 3(2), 156-167. https://doi.org/10.36778/jesya.v3i2.193

Simandjuntak, R. (2014). Pengaturan Penyelessaian Sengketa Pajak (Ditinjau dari Aspek Keadilan). Kumpulan Jurnal Mahasiswa Fakultas Hukum, 1(1), 1-17. 
Volume 2 No. 1, 2022

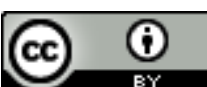

Siregar, D. L. (2017). Pengaruh Kesadaran Wajib Pajak dan sanksi Pajak Terhadap Kepatuhan Wajib Pajak Orang Pribadi pada Kantor Pelayanan Pajak Pratama Batam. Journal of Accounting \& Management Innovation, 1(2), 119-128.

Sumarni, Y. (2020). Pandemi Covid 19: Tantangan Ekonomi dan Bisnis. Al-Intaj Jurnal Ekonomi Dan Perbankan Syariah, 2(1), 46-58. https://ejournal.iainbengkulu.ac.id/index.php/Al-Intaj/article/viewFile/3358/2666

Tahar, A., \& Rachman, A. K. (2014). Pengaruh Faktor Internal dan Faktor Eksternal Terhadap Kepatuhan Wajib Pajak. Jurnal Akuntansi Dan Investasi, 15(1), 56-67.

Usman, A. H. (2014). Kesadaran Hukum Masyarakat dan Pemerintah Sebagai faktor Tegaknya Negara Hukum Di Indonesia. Jurnal Wawasan Hukum, 30(1), 26-53.

Valianti, R. M., Lilianti, E., Darwin, J., \& Saladin, H. (2021). Sadar Pajak Sejak Dini dalam Pendidikan. Jurnal PKM: Pengabdian Kepada Masyarakat, 04(02), 130-137. 